\title{
SOIL CHEMICAL PROPERTIES IN BANANA CROPS FERTIGATED WITH TREATED WASTEWATER ${ }^{1}$
}

\author{
PABLO FERNANDO SANTOS ALVES ${ }^{2}$, SILVÂNIO RODRIGUES DOS SANTOS ${ }^{2}$, MARCOS KOITI KONDO ${ }^{2}$, \\ RODINEI FACCO PEGORARO ${ }^{3}$, ARLEY FIGUEIREDO PORTUGAL ${ }^{4}$
}

\begin{abstract}
Determining the effects of using wastewater as fertilizer on soil chemical properties allows a safe reuse of this effluent in agriculture. This study evaluated the effects of fertigation with tertiary treated wastewater (TTW) from the Janaúba sewage treatment plant on chemical properties of a Latosol (Oxisol) with banana crops of the Prata-Anã cultivar in the semiarid region of Brazil. A randomized complete block design with four replications was used to test four TTW rates $\left(70 \%, 130 \%, 170 \%\right.$, and $200 \%$ of the limit of $150 \mathrm{~kg} \mathrm{ha}^{-1}$ year $^{-1}$ of $\mathrm{Na}$ that can be applied to the soil) and compare them to a control without TTW. Soil samples from the $0.0-0.2,0.2-0.4,0.4-0.6$, and $0.6-0.8 \mathrm{~m}$ layers were collected at the end of the first crop cycle to evaluate soil chemical properties- $\mathrm{pH}$, soil organic matter $(\mathrm{SOM}), \mathrm{P}, \mathrm{K}, \mathrm{Na}, \mathrm{Ca}, \mathrm{Mg}, \mathrm{Al}$, potential acidity $(\mathrm{H}+\mathrm{Al})$, base saturation, $\mathrm{B}, \mathrm{Cu}, \mathrm{Fe}, \mathrm{Mn}, \mathrm{Zn}$, remaining $\mathrm{P}$, and electrical conductivity (EC). The use of TTW increases soil $\mathrm{pH}$ and decreases exchangeable $\mathrm{Al}$ content, thus, reduces the need for liming. However, $\mathrm{Na}$ contents increased faster than EC in the soil, indicating that the use of TTW tends to alter soil physical properties over time. The use of TTW had no effect on the soil OM, P, Ca, Mg, and micronutrients contents, potential acidity, and base saturation. The changes in soil chemical attributes observed at the end of the first crop cycle were not limiting to the banana crop.
\end{abstract}

Keywords: Water reuse. Sewage. Effluent. Sodium. Plant nutrition.

\section{ATRIBUTOS QUÍMICOS DO SOLO EM BANANAL FERTIRRIGADO COM ÁGUA RESIDUÁRIA SANITÁRIA TRATADA}

RESUMO - Estabelecer os efeitos da aplicação de águas residuárias nos atributos químicos do solo permite o reúso agrícola seguro desses efluentes. Objetivou-se avaliar as alterações nos atributos químicos de um Latossolo no semiárido, cultivado com banana 'Prata-Anã' fertirrigada com diferentes doses de água residuária sanitária após tratamento terciário (ART) da Estação de Tratamento de Esgoto de Janaúba - MG. O experimento foi conduzido no delineamento em blocos completos casualizados. As doses de ART avaliadas foram equivalentes a 70, 130, 170 e $200 \%$ do limite de $150 \mathrm{~kg} \mathrm{ha}^{-1} \mathrm{ano}^{-1}$ de $\mathrm{Na}$ aportado ao solo, sendo também conduzido uma testemunha, sem ART. Ao final do primeiro ciclo de cultivo, foram coletadas amostras de solo nas profundidades de 0-0,2, 0,2-0,4, 0,4-0,6 e 0,6-0,8 m, determinando-se alguns atributos químicos. O uso de ART aumenta o $\mathrm{pH}$ do solo e reduz o teor de Al trocável, contribuindo para a substituição parcial do uso de corretivos de acidez. No entanto, com o aumento no teor de $\mathrm{Na}$ mais rápido que a $\mathrm{CE}$ do solo ao final do primeiro ciclo de produção da bananeira 'Prata-anã', há tendência de alterações nas propriedades físicas do solo em longo prazo, com a utilização da ART. No curto prazo, o uso de ART não influencia os teores de MOS, P, $\mathrm{Ca}, \mathrm{Mg}, \mathrm{H}+\mathrm{Al}, \mathrm{V}$ e os micronutrientes no solo. As modificações nos atributos químicos do solo ao final do primeiro ciclo de produção da bananeira não se apresentam restritivas para o cultivo.

Palavras-chave: Reúso de água. Esgoto. Efluente. Sódio. Nutrição de plantas.

\footnotetext{
${ }^{*}$ Corresponding author

${ }^{1}$ Received for publication in $11 / 20 / 2017$; accepted in $12 / 05 / 2018$.

Paper extracted from the master dissertation of the first author.

${ }^{2}$ Department of Agricultural Sciences, Universidade Estadual de Montes Claros, Janaúba, MG, Brazil; agrotecnico10@yahoo.com.br ORCID: 0000-0001-9715-9111, silvanio.santos@unimontes.br - ORCID: 0000-0003-0245-9184, marcos.kondo@unimontes.br - ORCID: 0000-0001-6875-4907.

${ }^{3}$ Institute of Agrarian Sciences, Universidade Federal de Minas Gerais, Montes Claros, MG, Brazil; rodinei_pegoraro@yahoo.com.br ORCID: 0000-0002-8692-9296.

${ }^{4}$ Embrapa Maize \& Sorghum, Empresa Brasileira de Pesquisa Agropecuária, Nova Porterinha, MG, Brazil; arley.portugal@embrapa.br ORCID: 0000-0001-6056-3233.
} 


\section{INTRODUCTION}

The composition of the sewage discharged into water bodies should meet the requirements of the Brazilian National Council for Environment (Conama) (BRASIL, 2005), and is a concern for effluent treatment systems. However, the nutrients in its composition enable the use of wastewaters because they are necessary inputs for crops (MOTA; VON SPERLING, 2009). Studies report positive and negative effects of nutrients in wastewater on soil chemical attributes (MEDEIROS et al., 2005; ERTHAL et al., 2010; SANTOS et al., 2017).

The use of wastewaters should follow some criteria to avoid chemical imbalance, changes in soil physical properties, phytotoxicity due to dissolved salts, increase in sodium contents over other ions, and presence of toxic ions, increasing the risk of turn the soil saline or sodic, initiating a desertification process (AYERS; WESTCOT, 1991; KHAN; ABDULLAH, 2003; SANTOS et al., 2015; ELGALLAL; FLETCHER; EVANS, 2016).

Fertigation with wastewater increases soil organic matter (BLUM et al., 2013; SANTOS et al., 2015; RAHEB; HEIDARI; MAHMOODI, 2017). Increases in soil organic colloids and ion concentration due to the use of wastewaters alter the soil cation exchange capacity, and nutrient $\left(\mathrm{K}^{+}, \mathrm{Ca}^{2+}\right.$, and $\left.\mathrm{Mg}^{2+}\right)$ adsorption by plants, increasing soil base saturation (ERTHAL et al., 2010).

The effects of wastewater on soil $\mathrm{pH}$ are contradictory; some studies indicate positive effects QUEIROZ et al., 2004; ANAMI et al., 2008) and others indicate no effects (GOMES et al., 2004; DUARTE et al., 2008; BEDBABIS et al., 2014). These results may be related to specific characteristics of each wastewater, soil used, and environmental factors of each study.

The use of wastewaters in banana crops alter soil organic matter and sodium contents (ALVES et al., 2015) and increases phosphorus, sulfur, total acidity, and base saturation levels in subsurface layers of irrigated soils (SANDRI; ROSA, 2017). These effects vary depending on the effluent composition, application management, and edaphic conditions.

The use of wastewater can change soil chemical attributes that affect the development of plants, especially banana, thus, stablishing safe rates of wastewater for fertigation is important. In this context, the objective of this study was to evaluate the effects of fertigation with tertiary treated wastewater on chemical properties of a Latosol (Oxisol) with banana crops of the Prata-Anã cultivar in the semiarid region of Brazil.

\section{MATERIAL AND METHODS}

The experiment was conducted at the experimental area of the sewage treatment plant of the Minas Gerais Water Supply Company (COPASA), in Janaúba, state of Minas Gerais, Brazil $\left(15^{\circ} 46^{\prime} 15^{\prime \prime} \mathrm{S}, 43^{\circ} 19^{\prime} 12^{\prime \prime} \mathrm{W}\right.$, and altitude of $\left.534 \mathrm{~m}\right)$. The climate of the region is Aw, tropical with dry winter, according to the Köppen classification, with average annual rainfall of $781 \mathrm{~mm}$, and average annual air temperature of $24.9^{\circ} \mathrm{C}$.

The soil of the experimental area was classified as eutrophic Red Latosol (Oxisol) (EMBRAPA, 2013). It had been used for grazing for more than 5 years, and presented degraded pastures, signs of compaction, and low organic matter content. Thus, the soil was prepared with subsoiling, plowing, harrowing, and opening of furrows for planting.

A randomized complete block design with four replications was used, consisting of four tertiary treated wastewater (TTW) rates, and a control without TTW. The wastewater used was previously subjected to tertiary treatment, passing through a grid, sand remover, upflow anaerobic sludge blanket (UASB), a facultative pond, and two maturation ponds. TTW rates were defined considering the maximum limit of annual application of sodium to the soil (LS) (150 $\left.\mathrm{kg} \mathrm{ha}^{-1}\right)$ (LARCHER, 2005). The treatments consisted of a Control with clean water + mineral fertilizer (T1), TTW at 70\% (T2), 130\% (T3), 170\% (T4), and 200\% (T5) of the LS. Clean water was applied to meet the crop requirements after each TTW application, both using a microsprinkler irrigation system.

Micropropagated banana seedlings of the Prata-anã cultivar were planted in May 2012, with spacing of $3 \times 2 \mathrm{~m}$ and plots consisting of four rows of 6 plants, totaling 24 plants per plot.

Planting fertilization was carried out 15 days before planting, based on soil analysis (Table 1), according to the recommendations of Borges (2004). NPK (4-30-10), single superphosphate, and FTE BR12 were applied to the planting furrows, providing $\mathrm{N}\left(22.8 \mathrm{~kg} \mathrm{ha}^{-1}\right), \mathrm{P}_{2} \mathrm{O}_{5}\left(200.0 \mathrm{~kg} \mathrm{ha}^{-1}\right), \mathrm{K}_{2} \mathrm{O}$ $\left(50.0 \mathrm{~kg} \mathrm{ha}^{-1}\right), \mathrm{S}\left(48.6 \mathrm{~kg} \mathrm{ha}^{-1}\right), \mathrm{Ca}\left(103.9 \mathrm{~kg} \mathrm{ha}^{-1}\right), \mathrm{B}$ $\left(1.5 \mathrm{~kg} \mathrm{ha}^{-1}\right), \mathrm{Cu}\left(0.7 \mathrm{~kg} \mathrm{ha}^{-1}\right), \mathrm{Mn}\left(1.7 \mathrm{~kg} \mathrm{ha}^{-1}\right), \mathrm{Mo}$ $\left(0.1 \mathrm{~kg} \mathrm{ha}^{-1}\right)$, and $\mathrm{Zn}\left(7.5 \mathrm{~kg} \mathrm{ha}^{-1}\right)$ to the plants.

The TTW rates were weekly applied through fertigation from 41 days after planting (DAP). Chemical fertilizations were applied from 90 DAP through fertigation with nitrogen and potassium as side dressing for the control treatment, and as complementary fertilization for the treatments with TTW, aiming to supply all plots with similar rates of these nutrients. 
P. F. S. ALVES et al.

Table 1. Physical and chemical attributes of the soil of the experimental area before the implementation of the experiment.

\begin{tabular}{|c|c|c|c|c|c|c|c|c|c|c|c|}
\hline $\begin{array}{l}\text { Layer } \\
(\mathrm{m})\end{array}$ & SD & $\mathrm{g} \mathrm{cm}^{-3} \stackrel{P D}{ }$ & $\begin{array}{c}\mathrm{TP} \\
\mathrm{m}^{3} \mathrm{~m}^{-3}\end{array}$ & VCS & $\mathrm{CS}$ & MS & FS & $\begin{array}{c}\text { VFS } \\
\mathrm{g} \mathrm{kg}^{-1}\end{array}$ & TS & Silt & Clay \\
\hline $0-0.2$ & 1.77 & 2.58 & 0.31 & 20 & 85 & 150 & 180 & 86 & 521 & 185 & 294 \\
\hline $0.2-0.4$ & 1.66 & 2.54 & 0.34 & 20 & 75 & 143 & 177 & 79 & 494 & 172 & 334 \\
\hline $0.4-0.6$ & 1.57 & 2.53 & 0.37 & 19 & 67 & 126 & 153 & 75 & 441 & 157 & 403 \\
\hline $0.6-0.8$ & 1.52 & 2.62 & 0.42 & 19 & 62 & 109 & 144 & 78 & 411 & 210 & 379 \\
\hline $\begin{array}{c}\text { Layer } \\
(\mathrm{m})\end{array}$ & $\begin{array}{c}\mathrm{pH} \\
\left(\mathrm{H}_{2} \mathrm{O}\right)\end{array}$ & $\begin{array}{c}{ }^{\mathrm{OM}} \\
\text { dag kg }^{-1}\end{array}$ & $\begin{array}{l}{ }^{2} \mathrm{P} \\
-\mathrm{mg}\end{array}$ & ${ }^{2} \mathrm{~K}$ & ${ }^{2} \mathrm{Na}$ & ${ }^{3} \mathrm{Ca}$ & ${ }^{3} \mathrm{Mg}$ & $\begin{array}{l}{ }^{3} \mathrm{Al} \\
\mathrm{cmol}_{\mathrm{c}}\end{array}$ & ${ }^{4} \mathrm{H}+\mathrm{Al}$ & ${ }^{5} \mathrm{SB}$ & ${ }^{6} \mathrm{CEC}$ \\
\hline $0-0.2$ & 6.2 & 1.3 & 2.3 & 260 & 0.1 & 2.8 & 0.9 & 0 & 2.2 & 4.5 & 6.7 \\
\hline $0.2-0.4$ & 5.5 & 0.7 & 2.0 & 140 & 0.1 & 2.2 & 0.7 & 0 & 2.2 & 3.4 & 5.6 \\
\hline $\begin{array}{c}\text { Layer } \\
(\mathrm{m})\end{array}$ & ${ }^{7} \mathrm{BS}$ & $-\%$ & ${ }^{9} \mathrm{~B}$ & $\begin{array}{r}{ }^{2} \mathrm{Cu} \\
-\mathrm{m} \\
\end{array}$ & $\begin{array}{l}{ }^{2} \mathrm{Fe} \\
\mathrm{m}^{-3}\end{array}$ & ${ }^{2} \mathrm{Mn}$ & ${ }^{2} \mathrm{Zn}$ & $\begin{array}{l}{ }^{10} \mathrm{P} \text {-rem } \\
\mathrm{mg} \mathrm{L}^{-1}\end{array}$ & $\begin{array}{c}{ }^{11} \mathrm{EC} \\
\mathrm{dS} \mathrm{m}^{-1}\end{array}$ & & \\
\hline $0-0.2$ & 67 & 0 & 0.3 & 1.0 & 23.7 & 10.8 & 0.8 & 35.2 & 0.3 & & \\
\hline $0.2-0.4$ & 61 & 0 & 0.4 & 0.9 & 24.8 & 3.9 & 0.4 & 30.6 & 0.2 & & \\
\hline
\end{tabular}

$\mathrm{SD}=$ soil density; $\mathrm{PD}=$ particle density; $\mathrm{TP}=$ total porosity; $\mathrm{VCS}=$ very coarse sand; $\mathrm{CS}=$ coarse sand; $\mathrm{MS}=$ medium sand; FS = fine sand; VFS = very fine sand; TS = total sand; ${ }^{1}$ determined by colorimetry; ${ }^{2}$ determined by Mehlich-1 extractor; ${ }^{3}$ determined by $\mathrm{KCl} 1 \mathrm{~mol} \mathrm{~L}-1$ extractor; ${ }^{4} \mathrm{pH}-\mathrm{SMP}$ estimator; ${ }^{5} \mathrm{SB}=$ sum of bases; ${ }^{6} \mathrm{CEC}=$ cátion Exchange capacity at $\mathrm{pH} 7 ;{ }^{7} \mathrm{BS}=$ base saturation; ${ }^{8} \mathrm{~m}=$ aluminum saturation; ${ }^{9} \mathrm{BaCl}_{2}$ extractor; ${ }^{10}$ Prem $=$ remaining $\mathrm{P} ;{ }^{11} \mathrm{EC}=$ electrical conductivity of the saturated soil extract of the ratio of 1:0.5 (soil:water).

The crop irrigation management consisted of irrigations with 2-day intervals, based on the crop evapotranspiration $\left(\mathrm{ET}_{\mathrm{c}}\right)$ calculated by multiplying the daily reference evapotranspiration $\left(\mathrm{ET}_{0}\right)$ by the crop coefficient $\left(\mathrm{K}_{\mathrm{c}}\right)$, location coefficient $\left(\mathrm{K}_{\mathrm{L}}\right)$, and soil coefficient $\left(\mathrm{K}_{\mathrm{s}}\right)$. $\mathrm{ET}_{0}$ was determined by the Penman-Monteith method (ALLEN et al., 2006) using data from a portable meteorological station installed in the experimental area. The $\mathrm{ET}_{\mathrm{c}}$, application efficiency $\left(E_{a}\right)$, arrangement $\left(18 \mathrm{~m}^{2}\right.$ emitter $\left.{ }^{-1}\right)$, and average emitter flow $\left(\mathrm{q}_{\mathrm{a}}\right)$ data were used to calculate the net and gross depths, and irrigation times. The micro-sprinkler irrigation system consisted of one emitter for every three plants with average flow of $76 \mathrm{~L} \mathrm{~h}^{-1}$ and working pressure of $200 \mathrm{kPa}$, and had $\mathrm{E}_{\mathrm{a}}$ of $96 \%$. Cultural practices followed the recommendations for the crop. The $\mathrm{K}_{\mathrm{c}}$ used varied from 0.7 (beginning of cycle) to 1.3 (flowering/fruiting), and was 1.1 at the fruit ripening (OLIVEIRA et al., 2005).

Simple samples of TTW were collected monthly at the end of one of the lateral lines during the applications and sent to a laboratory to determine total nitrogen, ammonia nitrogen, nitrate nitrogen, organic nitrogen, $\mathrm{K}, \mathrm{Na}, \mathrm{P}, \mathrm{Zn}, \mathrm{Cu}, \mathrm{Fe}, \mathrm{Mn}, \mathrm{B}, \mathrm{Cl}^{-}$, $\mathrm{Co}, \mathrm{Ca}, \mathrm{Mg}$, electrical conductivity, chemical oxygen demand, biochemical oxygen demand, oils and greases, $\mathrm{pH}$, total suspended solids, total coliforms, and Escherichia coli (E. coli) (Table 2), according to the APHA et al. (2012). The results of the previous month were used to calculate the TTW fertigation rates for the treatments (Table 3 ).

Table 2. Characteristics of the tertiary treated wastewater (TTW) from the Janaúba sewage treatment plant, collected between June 2012 and June 2014.

\begin{tabular}{|c|c|c|c|c|}
\hline Component of TTW & Unit & mean & \multicolumn{2}{|c|}{ standard deviation } \\
\hline TN & $\mathrm{mg} \mathrm{L}^{-1}$ & 47.6 & \pm & 8.6364 \\
\hline AN & $\mathrm{mg} \mathrm{L}^{-1}$ & 35.7 & \pm & 9.6572 \\
\hline NN & $\mathrm{mg} \mathrm{L}^{-1}$ & 1.08 & \pm & 1.7207 \\
\hline ON & $\mathrm{mg} \mathrm{L}^{-1}$ & 10.82 & \pm & 8.0942 \\
\hline $\mathrm{K}$ & $\mathrm{mg} \mathrm{L}^{-1}$ & 33.939 & \pm & 11.1534 \\
\hline $\mathrm{Na}$ & $\mathrm{mg} \mathrm{L}^{-1}$ & 84.369 & \pm & 19.4586 \\
\hline $\mathrm{P}$ & $\mathrm{mg} \mathrm{L}^{-1}$ & 8.218 & \pm & 1.6438 \\
\hline $\mathrm{Zn}^{*}$ & $\mathrm{mg} \mathrm{L}^{-1}$ & 0.088 & \pm & 0.0601 \\
\hline $\mathrm{Cu}$ & $\mathrm{mg} \mathrm{L}^{-1}$ & 0.008 & \pm & 0.0011 \\
\hline $\mathrm{Fe}$ & $\mathrm{mg} \mathrm{L}^{-1}$ & 0.68 & \pm & 0.2875 \\
\hline $\mathrm{Mn}$ & $\mathrm{mg} \mathrm{L}^{-1}$ & 0.1 & \pm & 0.0102 \\
\hline $\mathrm{B}$ & $\mathrm{mg} \mathrm{L}^{-1}$ & 0.023 & \pm & 0.0084 \\
\hline $\mathrm{Cl}^{-}$ & $\mathrm{mg} \mathrm{L}^{-1}$ & 130.6 & \pm & 28.2479 \\
\hline Co & $\mathrm{mg} \mathrm{L}^{-1}$ & 0.001 & \pm & 0.0086 \\
\hline $\mathrm{Ca}$ & $\mathrm{mg} \mathrm{L}^{-1}$ & 19.134 & \pm & 4.9072 \\
\hline $\mathrm{Mg}^{*}$ & $\mathrm{mg} \mathrm{L}^{-1}$ & 7.963 & \pm & 3.7786 \\
\hline $\mathrm{EC}$ & $\mathrm{dS} \mathrm{m}^{-1}$ & 1.128 & \pm & 0.1619 \\
\hline COD & $\mathrm{mg} \mathrm{L}^{-1}$ & 174.8 & \pm & 35.1715 \\
\hline BOD & $\mathrm{mg} \mathrm{L}^{-1}$ & 58.88 & \pm & 16.8785 \\
\hline OG & $\mathrm{mg} \mathrm{L}^{-1}$ & 11.0 & \pm & 4.1227 \\
\hline $\mathrm{pH}$ & & 7.604 & \pm & 0.2467 \\
\hline TSS & $\mathrm{mg} \mathrm{L}^{-1}$ & 70.2 & \pm & 33.8934 \\
\hline $\mathrm{TC}$ & CFU $(100 \mathrm{~mL})^{-1}$ & $5.01 \mathrm{E}+06$ & \pm & $4.32 \mathrm{E}+06$ \\
\hline E. coli & MPN $(100 \mathrm{~mL})^{-1}$ & $9.60 \mathrm{E}+03$ & \pm & $3.16 \mathrm{E}+05$ \\
\hline
\end{tabular}

$\mathrm{TN}=$ total nitrogen; $\mathrm{AN}=$ ammonia nitrogen; $\mathrm{NN}=$ nitrate nitrogen; $\mathrm{ON}=$ organic nitrogen; $\mathrm{EC}=$ electrical condutivity; $\mathrm{COD}=$ total chemical oxygen demand; $\mathrm{BOD}=$ total biochemical oxygen demand; OG: oils and greases; TSS $=$ total suspended solids; TC: total coliforms; E. coli: Escherichia coli; * = quantified only from 02/2013.

Rev. Caatinga, Mossoró, v. 32, n. 1, p. 234 - 242, jan. - mar., 2019 
Table 3. Rates of the tertiary treated wastewater (TTW), and means of the main nutrients added to the soil in each treatment (Treat.) during the first cycle (planting to first harvest at 434 days after planting) of the banana crops of the PrataAnã cultivar.

\begin{tabular}{|c|c|c|c|c|c|c|c|c|c|c|c|}
\hline Treat. & \multicolumn{3}{|c|}{ TTW } & \multicolumn{2}{|c|}{ Rainfall } & & \multicolumn{2}{|c|}{ CWD } & \multicolumn{3}{|c|}{ Total } \\
\hline Control & \multicolumn{3}{|c|}{0} & \multicolumn{2}{|c|}{432.8} & & \multicolumn{2}{|c|}{2205.2} & \multicolumn{3}{|c|}{2638} \\
\hline 70 & \multicolumn{3}{|c|}{127.1} & \multicolumn{2}{|c|}{432.8} & & \multicolumn{2}{|c|}{2078.1} & \multicolumn{3}{|c|}{2638} \\
\hline 130 & \multicolumn{3}{|c|}{252.7} & \multicolumn{2}{|c|}{432.8} & & \multicolumn{2}{|c|}{1952.5} & \multicolumn{3}{|c|}{2638} \\
\hline 170 & \multicolumn{3}{|c|}{312.5} & \multicolumn{2}{|c|}{432.8} & & \multicolumn{2}{|c|}{1892.7} & \multicolumn{3}{|c|}{2638} \\
\hline 200 & & 373.4 & & \multicolumn{2}{|c|}{432.8} & & \multicolumn{2}{|c|}{1831.8} & \multicolumn{3}{|c|}{2638} \\
\hline \multirow{3}{*}{ Treat. } & \multicolumn{11}{|c|}{ Nutrients added to the soil $\left(\mathrm{kg} \mathrm{ha}^{-1}\right)$} \\
\hline & \multicolumn{3}{|c|}{$-\mathrm{TN}-$} & \multicolumn{2}{|c|}{$\mathrm{P}_{2} \mathrm{O}_{5}$} & & \multirow{2}{*}{$\mathrm{MF}$} & \multirow{2}{*}{$\begin{array}{l}-\mathrm{K}_{2} \mathrm{O}- \\
\text { TTW }\end{array}$} & \multirow[b]{2}{*}{ Sum } & \multicolumn{2}{|c|}{$-\mathrm{Na}$} \\
\hline & MF & TTW & Sum & MF & TTW & Sum & & & & TTW & Sum \\
\hline Control & 226.2 & 0.0 & 226.2 & 200.0 & 0.0 & 200.0 & 253.3 & 0.0 & 253.3 & 0.0 & 0.0 \\
\hline 70 & 143.3 & 86.6 & 229.9 & 200.0 & 27.5 & 227.5 & 198.2 & 58.1 & 256.3 & 103.8 & 103.8 \\
\hline 130 & 120.8 & 114.2 & 235.0 & 200.0 & 55.0 & 255.0 & 143.7 & 115.6 & 259.3 & 206.5 & 206.5 \\
\hline 170 & 109.8 & 127.6 & 237.4 & 200.0 & 67.8 & 267.8 & 117.2 & 142.5 & 259.7 & 255.2 & 255.2 \\
\hline 200 & 98.5 & 141.0 & 239.5 & 200.0 & 81.3 & 281.3 & 90.2 & 170.3 & 260.5 & 304.8 & 304.8 \\
\hline
\end{tabular}

Rainfall = effective precipitation; CWD = complementary water irrigation depths; Total $=$ total depths applied in the experimental plots; $\mathrm{MF}=$ mineral fertilization; $\mathrm{TN}$ $=$ total nitrogen available for the crop; Control = clean water and side dressing fertilization with mineral fertilizer; $70=70 \% ; 130=130 \% ; 170=170 \% ; 200=200 \%$ of the limit of $150 \mathrm{~kg} \mathrm{ha}^{-1}$ year $^{-1}$ of Na applied to the soil (LARCHER, 2005).

Four simple soil samples from the 0.0-0.2, 0.2 $-0.4,0.4-0.6$, and $0.6-0.8 \mathrm{~m}$ layers were collected between the micro-sprinkler lines at the end of the first crop cycle (434 DAP) to form a composite sample to determine $\mathrm{pH}, \mathrm{OM}, \mathrm{P}, \mathrm{K}, \mathrm{Na}, \mathrm{Ca}, \mathrm{Mg}, \mathrm{Al}$, $\mathrm{H}+\mathrm{Al}$, base saturation, $\mathrm{B}, \mathrm{Cu}, \mathrm{Fe}, \mathrm{Mn}, \mathrm{Zn}$, reaming $\mathrm{P}$, and electrical conductivity of the saturated soil extract.

The data of soil chemical attributes were subjected to individual analysis of variance for each soil layer; regression analysis was performed when $\mathrm{F}$ was significant up to $5 \%$ level. Means of the TTW treatments and control were compared using the Dunnett's test at 5\% significance.

\section{RESULTS AND DISCUSSION}

The fertigation with tertiary treated wastewater (TTW) changed the soil $\mathrm{pH}, \mathrm{K}, \mathrm{Na}$, and electrical conductivity (EC) at the end of the first banana crop cycle (Table 4).

Table 4. Means of the treatments and Dunnett's test for soil chemical attributes at 434 days after planting of banana of the Prata-Anã cultivar fertigated with tertiary treated wastewater (TTW).

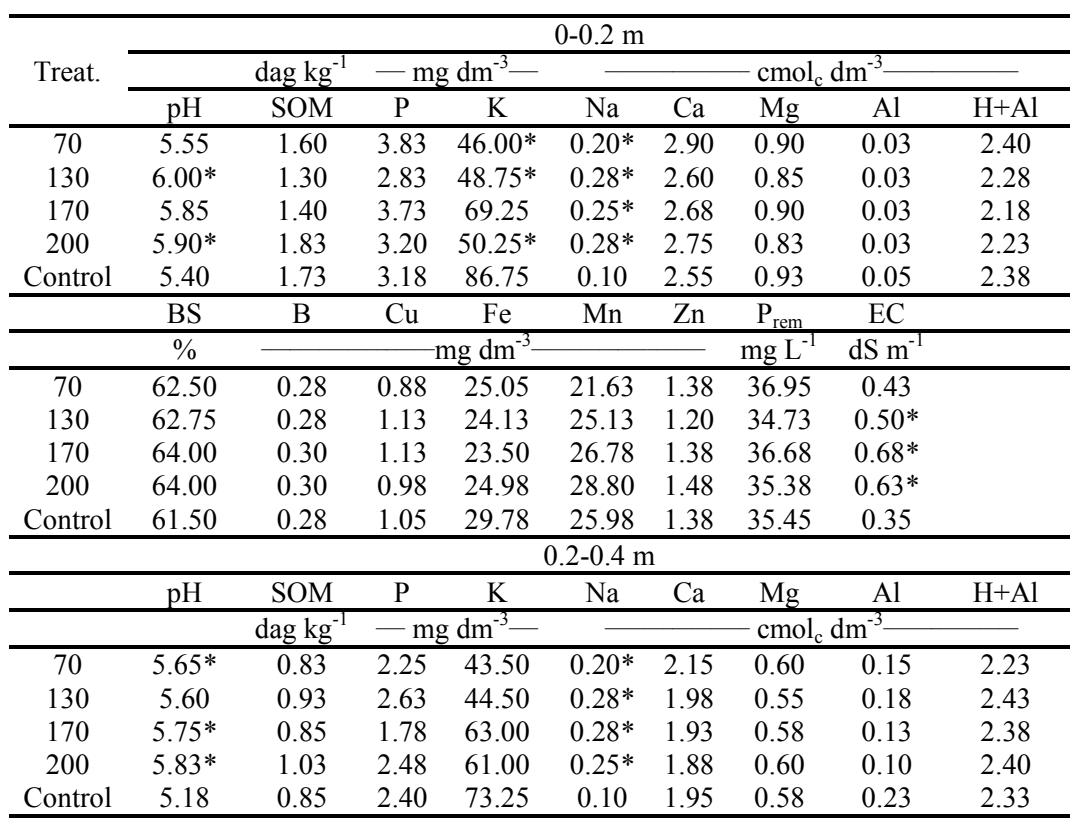

Means followed by an asterisk in the same soil layer differ from the control by the Dunnett's test at $5 \%$ significance. SOM = organic matter; $\mathrm{H}+\mathrm{Al}=$ potential acidity, $\mathrm{BS}=$ base saturation; $\mathrm{P}_{\mathrm{rem}}=$ remaining $\mathrm{P} ; \mathrm{EC}=$ electrical conductivity. Control $=$ clean water and side dressing fertilization with mineral fertilizer; $70=70 \% ; 130=130 \% ; 170=170 \% ; 200=200 \%$ of the limit of $150 \mathrm{~kg} \mathrm{ha}^{-1}$ year ${ }^{-1}$ of $\mathrm{Na}$ applied to the soil (LARCHER, 2005) 
P. F. S. ALVES et al.

Table 4. Continued.

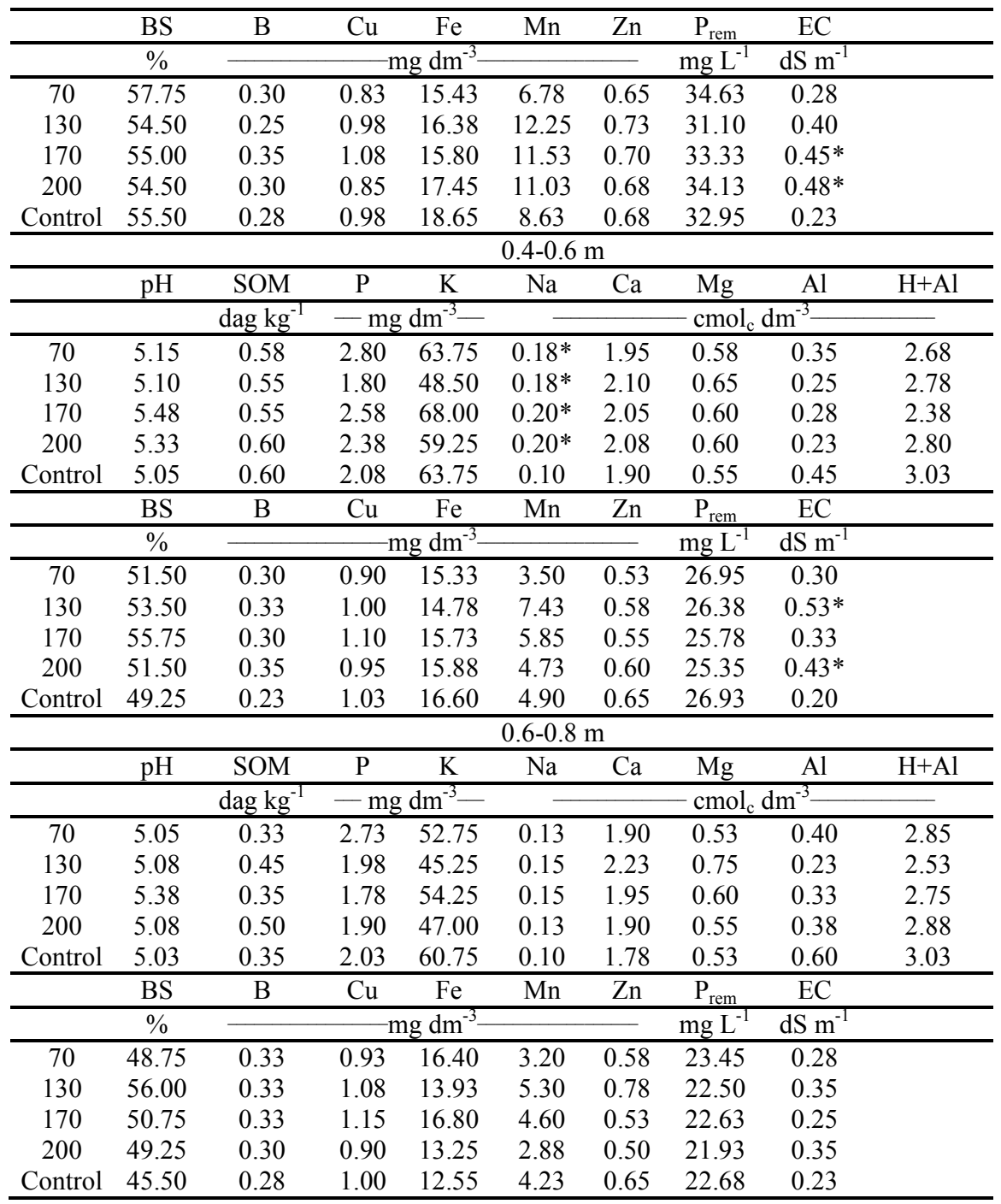

Means followed by an asterisk in the same soil layer differ from the control by the Dunnett's test at $5 \%$ significance. $\mathrm{SOM}=$ organic matter; $\mathrm{H}+\mathrm{Al}=$ potential acidity, $\mathrm{BS}=$ base saturation; $\mathrm{P}_{\text {rem }}=$ remaining $\mathrm{P} ; \mathrm{EC}=$ electrical conductivity. Control = clean water and side dressing fertilization with mineral fertilizer; $70=70 \% ; 130=130 \% ; 170=$ $170 \% ; 200=200 \%$ of the limit of $150 \mathrm{~kg} \mathrm{ha}^{-1}$ year $^{-1}$ of $\mathrm{Na}$ applied to the soil (LARCHER, 2005).

The soil chemical analysis after the first banana crop cycle showed that the soil $\mathrm{pH}$ increased with the use of TTW when compared to the Control (Table 4). It was probably due to the contribution of the TTW to the bases of the soil $(\mathrm{Ca}, \mathrm{Mg}, \mathrm{K}, \mathrm{Na})$. Similar results were found in others studies using wastewaters as source of water and nutrients (MEDEIROS et al., 2005; ANAMI et al., 2008; SMANHOTTO et al., 2010; MEDEIROS et al., 2011).

Increases in $\mathrm{pH}$ decrease $\mathrm{Al}^{3+}$ concentration in the soil, which allows cations of lower valance to dominate the exchange complex, favoring the expansion of the diffuse double layer (SILVA; CARVALHO, 2004). This improves mineral nutrition for banana crops because this plant species has high demand for cationic nutrients $(\mathrm{K}, \mathrm{Ca}$, and $\mathrm{Mg}$ ). The $\mathrm{pH}$ results found in the present work are agronomically good (Table 4), according to the criteria of Alvarez V. et al. (1999).

Soil organic matter (SOM) was not affected by the TTW treatments when compared to the Control (Table 4). Similar result was found by Santos et al. (2017) in successive maize, cotton, and common bean crops. SOM is usually altered by TTW after several years of use (XU et al., 2010); however, the use of high wastewater rates $(150 \%$ of the maximum water demand) in semiarid regions can raise the SOM (OLIVEIRA et al., 2016). The results of the present study showed an increase in SOM when compared to that before the experiment implementation (Table 1), presenting averages of 
$20.8 \%(0.0-0.2 \mathrm{~m}$ layer $)$ and $28.6 \%(0.2-0.4 \mathrm{~m}$ layer); this can be explained by the decomposition of plant residues, such as leaves and stems of banana trees in the experimental area.

Soil $\mathrm{P}$ contents were not affected by the TTW rates when compared to the Control, however, they increased by $45.6 \%(0.0-0.2 \mathrm{~m})$ and $15.5 \%(0.2-0.4$ $\mathrm{m}$ layer) when compared to $\mathrm{P}$ contents before the experiment. P contents remained very low, according to Alvarez V. et al. (1999).

Exchangeable $\mathrm{K}$ contents decreased in treatments with TTW (Table 4), except in the treatment with TTW at $170 \%$, which presented, in general, similar contents to those of the Control. Fertigation with wastewaters can increase contents of organic compounds that carry $\mathrm{K}$ in the soil, facilitating the leaching of this nutrient (OLIVEIRA; VILLAS BÔAS, 2008; DUARTE; PEREIRA; KORNDÖRFER, 2013). However, no increases in K was found in deeper soil layers (Table 4), indicating that the use of TTW contributed to the absorption of this nutrient by the banana plants, reducing soil $\mathrm{K}$ contents.

The chemical analysis showed significant reductions in soil $\mathrm{K}$ contents for all treatments at the end of the first crop cycle (Table 4) when compared to $\mathrm{K}$ contents before the experiment (Table 1), mainly in the soil surface layers. This denotes the need for a balanced replacement of $\mathrm{K}$ to avoid soil $\mathrm{K}$ exhaustion and decreasing in banana production. Medeiros et al. (2005) also found reduced K contents in soils treated with domestic wastewater for coffee plants.

The use of TTW increased soil Na contents$152.5 \%(0.0-0.2$ and $0.2-0.4 \mathrm{~m})$ and $90 \%(0.4-0.6 \mathrm{~m}$ layer) - when compared to the Control. Na contents did not increase in the $0.6-0.8 \mathrm{~m}$ soil layer because the irrigation was performed up to the depth of 0.6 $\mathrm{m}$

Excess sodium causes damages to soil physical (CORRÊA et al., 2003; SANTOS et al., 2015) and chemical properties (MEDEIROS et al., 2005; FERREIRA et al., 2011; SANTOS et al., 2017) and reduces plant growth, causing serious problems to agriculture (CAVALCANTE et al., 2010). The TTW treatments increased soil Na contents due to the high average concentration of this element $\left(84,37 \mathrm{mg} \mathrm{L}^{-1}\right)$ in the TTW, which explains the use of $\mathrm{Na}$ as the limiting element to determine the TTW rates to be used.

Similarly, the EC was not affected by TTW only in the $0.6-0.8 \mathrm{~m}$ layer (Table 4). Each $1 \%$ increase in the percentage of TTW rate increased EC in $0.0018 \mathrm{dS} \mathrm{m}^{-1}$ in the soil $0.0-0.2 \mathrm{~m}$ layer (Figure 1). In the $0.2-0.4 \mathrm{~m}$ soil layer, the highest TTW rates $(170 \%$ and $200 \%)$ increased EC in $95.7 \%$ and $108.7 \%$, respectively, compared to the Control. TTW rates affected the EC in the 0.4-0.6 m layer (Table 4 ), but the regression model used not efficiently explained this result.

Soil EC is proportional to its ionic concentration, i.e., it measures solutes (ions) in the soil solution and is widely used to measure soil salinity (FERREIRA et al., 2016). Thus, the increases in soil EC (Figure 1) may be associated with the dissolved ions in the TTW used. The EC of the TTW (mean of $1.13 \mathrm{dS} \mathrm{m}^{-1}$ ) (Table 2) indicated a medium risk of salinizing the soil (PIZARRO CABELLO, 1996), especially with the highest TTW rates applied (Figure 1). This denotes the need for caution when using wastewater to partially supply nutrients and water to crops to maintain the sustainability of the production system.

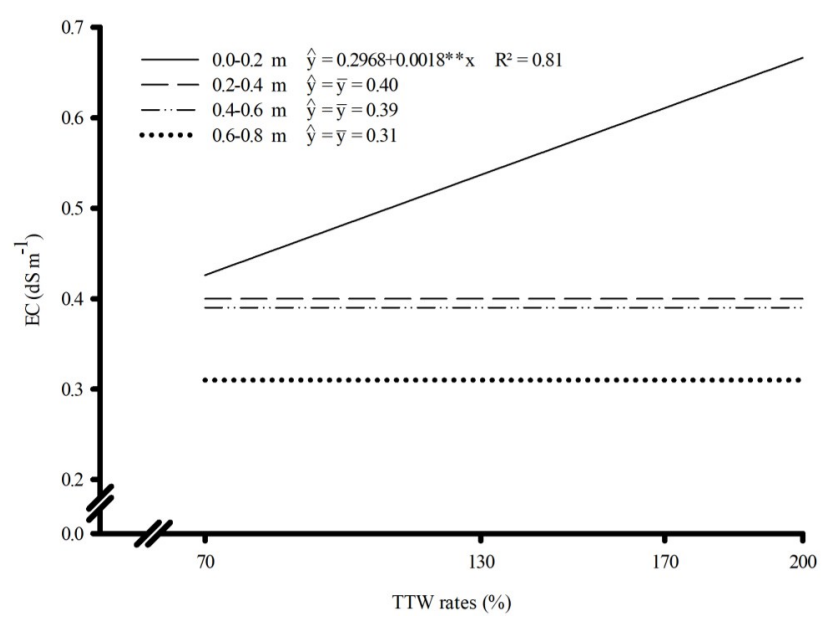

Figure 1. Electrical conductivity (EC) of a eutrophic Red Latosol (Oxisol) subjected to fertigation with tertiary treated wastewater (TTW) rates based on the limit of $150 \mathrm{~kg} \mathrm{ha}^{-1}$ year $^{-1}$ of Na.

$\mathrm{Na}$ contents increased with the use of TTW (Table 4), ranging from 103.8 to $304.8 \mathrm{~kg} \mathrm{ha}^{-1}$ (Table 3 ), and all treatments had higher $\mathrm{Na}$ contents than the control up to the soil depth of $0.6 \mathrm{~m}$. The EC found in the 0.4-0.6 m layer when using TTW at $170 \%$ was higher than that found when using TTW at $200 \%$. This was probably due to the percolation of other salts from the complementary fertilization, 
which together with Na increased soil EC. Souza and Moreira (2010) found similar results, with chemical fertilization causing more ionization of the soil solution than a swine wastewater.

The soil $\mathrm{Ca}, \mathrm{Mg}, \mathrm{Al}, \mathrm{H}+\mathrm{Al}$, base saturation, remaining $\mathrm{P}, \mathrm{B}, \mathrm{Cu}, \mathrm{Fe}, \mathrm{Mn}$, and $\mathrm{Zn}$ were not affected by the TTW treatments when compared to the Control. A large part of the banana root system is concentrated in the first $0.3 \mathrm{~m}$ of soil; thus, according to the criteria of Alvarez V. et al. (1999), the chemical analysis of the soil after one crop cycle of the Prata-Anã banana using TTW indicated that the levels of $\mathrm{Ca}$, and $\mathrm{Mg}$ contents, and base saturation was good; $\mathrm{Al}$ was very-low; $\mathrm{H}+\mathrm{Al}$, and $\mathrm{B}$ was low; Fe, and $\mathrm{Zn}$ was medium; and $\mathrm{Mn}$ was high.

\section{CONCLUSIONS}

The use of tertiary treated wastewater (TTW) for fertigation of banana crops increases soil $\mathrm{pH}$.

The TTW rates used increase soil $\mathrm{Na}$ contents, and electrical conductivity at the end of the first crop cycle of banana of the Prata-anã cultivar, which may restrict crop development over time.

The use of TTW does not affect soil organic matter, $\mathrm{P}, \mathrm{Ca}, \mathrm{Mg}, \mathrm{H}+\mathrm{Al}$, base saturation, and micronutrients at the end of the first banana crop cycle.

Changes in soil chemical attributes caused by the use of TTW, verified at the end of the first crop cycle, are not limiting to banana crops.

\section{ACKNOWLEDGMENTS}

The authors thank the Minas Gerais Water Supply Company (COPASA); the Banco do Nordeste (BNB); the Foundation for Research Support of the State of Minas Gerais (FAPEMIG); the Brazilian Coordination for the Improvement of Higher Education Personnel (CAPES); and the Brazilian Council for Scientific and Technological Development (CNPq) for the financial support, and granting scholarships.

\section{REFERENCES}

ALLEN, R. G. et al. Evapotranspiracióndel cultivo: guias para ladeterminación de losrequerimientos de agua de los cultivos. Rome: FAO, 2006. 320 p. (FAO Irrigationand Drainage, $56)$.

ALVAREZ V, V. H. et al. Interpretação dos resultados das análises de solos. Recomendação para o uso de corretivos e fertilizantes em Minas Gerais - 5-aproximação, p. 19-24, 1999.
ALVES, P. F. S. et al. Soil physical attributes in chemigated banana plantation with wastewater. Engenharia Agrícola, v. 35, n. 6, p. 998-1008, 2015.

ANAMI, M. H. et al. Deslocamento miscível de nitrato e fosfato proveniente de água residuária da suinocultura em colunas de solo. Revista Brasileira de Engenharia Agrícola e Ambiental, v. 12, n. 1, p. 75-80, 2008 .

$\begin{array}{llr}\text { AMERICAN PUBLIC HEALTH ASSOCIATION - } \\ \text { APHA; AMERICAN } & \text { WATER } & \text { WORKS } \\ \text { ASSOCIATION }- & \text { AWWA; } & \text { WATER }\end{array}$
ENVIRONMENT FEDERATION - WEF.Standard methods for the examination of water and wastewater. 22 ed. Washington: APHA/AWWA/ WEF, 2012. $1360 \mathrm{p}$.

AYERS, R. S.; WESTCOT, D. W. A qualidade da água na agricultura. Traduzido por GHEYI, H. R. et al. Campina Grande: UFPB/FAO, 1991. 218p. (FAO. Estudos Irrigação e Drenagem, 29)

BEDBABIS, S. et al. Effect of irrigation with treated wastewater on soil chemical properties and infiltration rate. Journal of Environmental Management, v. 133, n. 15, p. 45-50, 2014.

BLUM, J. et al. Nitrogen and Phosphorus leaching in a tropical Brazilian soil cropped with sugarcane and irrigated with treated sewage effluent. Agricultural Water Management, v. 117, n. 31, p. 115-122, 2013.

BORGES, A. L. Recomendação de adubação para a bananeira. Cruz das Almas: EMBRAPA, 2004. 4p. (Comunicado Técnico, 106).

BRASIL. Resolução CONAMA no 357/2005, de 17 de março de 2005. Dispõe sobre a classificação dos corpos de água e diretrizes ambientais para o seu enquadramento, bem como estabelece as condições e padrões de lançamento de efluentes, e dá outras providências. Diário Oficial da União, 18 de março de 2005 , p. $58-63$.

CAVALCANTE, L. F. et al. Fontes e níveis da salinidade da água na formação de mudas de mamoeiro cv. Sunrise solo. Semina: Ciências Agrárias, v. 31, n. 4, p. 1281-1290, 2010.

CORRÊA, M. M. et al. Atributos físicos, químicos e mineralógicos de solos da região das Várzeas de Sousa (PB). Revista Brasileira de Ciência do Solo, v. 27, n. 2, p. 311-324, 2003.

DUARTE, A. S. et al. Efeitos da aplicação de efluente tratado no solo: $\mathrm{pH}$, matéria orgânica, fósforo e potássio. Revista Brasileira de 
Engenharia Agrícola e Ambiental, v. 12, n. 3, p. 302-310, 2008.

DUARTE, I. N.; PEREIRA, H. S.; KORNDÖRFER, G. H. Lixiviação de potássio proveniente do termopotássio. Pesquisa Agropecuária Tropical, v. 43, n. 2, p. 195-200, 2013.

ELGALLAL, M.; FLETCHER, L.; EVANS, B. Assessment of potential risks associated with chemicals in wastewater used for irrigation in arid and semiarid zones: A review. Agricultural Water Management, v. 177, s/n, p. 419-431, 2016.

EMPRESA BRASILEIRA DE PESQUISA AGROPECUÁRIA - EMBRAPA. Centro Nacional de Pesquisa de Solos. Sistema brasileiro de classificação de solos. 3. ed. Rio de Janeiro, RJ: Embrapa-SPI, 2013. 353 p.

ERTHAL, V. J. T. et al. Alterações físicas e químicas de um Argissolo pela aplicação de água residuária de bovinocultura. Revista Brasileira de Engenharia Agrícola e Ambiental, v. 14, n. 5, p. 467-477, 2010.

FERREIRA, D. C. et al. Nutrient inputs in soilcultivatedwithcoffeecropfertigatedwithdomestics ewage. Ambiente\&Água-An Interdisciplinary Journal of Applied Science, v. 6, n. 3, p. 77-85, 2011.

FERREIRA, P. A.; DILVA, J. B. L. da; RUIZ, H. A. Aspectos físicos e químicos de solos em regiões áridas e semi-áridas. In: GHEYI, H. R.; DIAS, N. S.; LACERDA, C. F. (Eds.). Manejo da salinidade na agricultura. 2 ed. Fortaleza, INCT Sal, 2016. cap. 3, p. 17-34.

GOMES, E. R. S. et al. Movimento de nitrato proveniente de água residuária em colunas de solos. Engenharia Agrícola, v. 24, n. 3, p. 557-568, 2004.

KHAN, M. A.; ABDULLAH, Z. Salinity-sodicity induced changes in reproductive physiology of rice (Oryza sativa) under dense soil conditions. Environmental and Experimental Botany, v. 49, n. 2, p. 145-157, 2003.

LARCHER, W. Ecofisiologia Vegetal. 5 ed. São Carlos, SP: RIMA Artes e Textos, 2005. 550 p.

MEDEIROS, S. de S. et al. Características químicas do solo sob algodoeiro em área que recebeu água residuária da suinocultura. Revista Brasileira de Ciência do Solo, v. 35, n. 3, p. 1047-1055, 2011.

MEDEIROS, S. de S. et al. Utilização de água residuária de origem doméstica na agricultura: estudo das alterações químicas do solo. Revista
Brasileira de Engenharia Agrícola e Ambiental, v 9, n. 4, p. 603-612, 2005.

MOTA, S.; VON S. M. Nutrientes de esgoto sanitário: utilização e remoção. Rio de Janeiro, RJ: ABES, 2009. 428 p.

OLIVEIRA, M. V. A. M. de; VILLAS BÔAS, R. L. Uniformidade de distribuição do potássio e do nitrogênio em sistema de irrigação por gotejamento. Engenharia Agrícola, v. 28, n. 1, p. 95-103, 2008.

OLIVEIRA, S. L. et al. Uso da irrigação e da fertirrigação na produção integrada da banana no Norte de Minas Gerais. Cruz das Almas, BA. Embrapa Mandioca e Fruticultura, 2005. 7p. (Circular Técnica, 77).

OLIVEIRA, P. C. P. et al. Soil chemistry after irrigation with treated wastewater in semiarid climate. Revista Brasileira de Ciência do Solo, v. 40, n. 1, p. 1-13, 2016.

PIZARRO CABELLO, F. Riegos localizados de alta frecuencia (RLAF): goteo, microaspersión, exudación. 3 ed. Madrid: Ediciones Mundi-Prensa, 1996. $511 \mathrm{p}$.

QUEIROZ, F. M. et al. Características químicas de solo submetido ao tratamento com esterco líquido de suínos e cultivado com gramíneas forrageiras. Ciência Rural, v. 34, n. 5, p. 1487-1492, 2004.

RAHEB, A.; HEIDARI, A.; MAHMOODI, S. Organic and inorganic carbon storage in soils along an arid to dry sub-humid climosequence in northwest of Iran. Catena, v. 153, s/n, p. 66-74, 2017.

SANDRI, D.; ROSA, R. de R. B. Atributos químicos do solo irrigado com efluente de esgoto tratado, fertirrigação convencional e água de poço. Irriga, v. 22, n. 1, p. 18-33, 2017.

SANTOS, S. R.; et al. Changes in soil chemical properties promoted by fertigation with treated sanitary wastewater. Engenharia Agrícola, v. 37, n. 2, p. 343-352, 2017.

SANTOS, S. R. et al. Short-term changes in soil properties due to sanitary wastewater irrigation used as a potassium source. Australian Journal of Crop Science, v. 9, n. 8, p. 713-720, 2015.

SILVA, J. T. A.; CARVALHO, J. G..Propriedades do solo, estado nutricional e produtividade de bananeiras "prata anã" (aab) irrigadas com águas calcárias. Ciência e Agrotecnologia, v. 28, n. 2, p. 332-338, 2004 
SMANHOTTO, A. et al. Cobre e zinco no material percolado e no solo com a aplicação de água residuária de suinocultura em solo cultivado com soja. Engenharia Agrícola, v. 30, n. 2, p. 347-357, 2010 .

SOUZA, J. A. R.; MOREIRA, D. A. Efeitos do uso da água residuária da suinocultura na condutividade elétrica e hidráulica do solo. Engenharia Ambiental: Pesquisa e Tecnologia, v. 7, n. 3, p. 134-143, 2010.

$\mathrm{XU}, \mathrm{J}$. et al. Impact of long-term reclaimed wastewater irrigation on agricultural soils: a preliminary assessment. Journal of Hazardous Materials, v. 183, n. 1-3, p. 780-786, 2010. 